Web Site: https://jutq.utq.edu.iq/index.php/main

Email: journal@jutq.utq.edu.iq

\title{
Histopathological Study of Teratoma Diagnosis in Ovaries of Cattle at South of Iraq https://doi.org/10.32792/utq/utj/vol12/2/10
}

\section{Khalid Al-Fartosi ${ }^{1}$; Hazar Sh. Salah ${ }^{2}$; Layla M. Mehdi ${ }^{3}$ 1,2,3 Department of Biology, College of Education, University of Thi-Qar, Iraq.}

\begin{abstract}
Three cases of ovarian teratoma in bovine were diagnosed at first time in southern of Iraq. Through investigation of ovaries in 120 cows. Showed macroscopical description of ovaries lesions which were bilateral malignant tumors on external surface for each ovary (left and right).The specific characteristics of this tumor was presence of hair embedded within texture of lesion which represented to embryo remnants, As well as, the study revealed a histological exploration of tumor that. Granulosa cells under go different stages of mitotic divisions were noted during the histological study. Also tumor tissues represented as keratinized squamous epithelial tissue, contained skin adenxal structures such as hair follicle. The closed similarity between teratoma and epidermoid cysts results in misdiagnosis between them. The present study revealed that teratoma is more frequently incidence to the cattle than other demotic animal in addition this tumor had similar features to the teratoma in women.
\end{abstract}

\section{Key words: Cattle, Ovary, Follicle, Teratoma}

\section{Introduction:}

Teratoma is a types of tumor containing cysts was lined by keratinizing, stratified squamous epidermis which the same features with dermoid, whereas mixed with epidermoid cysts diagnosis (Pantoia et al., 1975). While epidermoid cysts are lined by stratified, cornifying and squamous epithelium filled with keratin debris or amorphous proteinaceous material without epidermal adnexal structures (Pantoia et al.,1975; Noales 


\section{University of Thi-Qar Journal Vol.12 No.2 June 2017 \\ Web Site: https://jutq.utq.edu.iq/index.php/main \\ Email: journal@jutq.utq.edu.iq}

and Silverberg ,1976).In human begins, the teratoma and epidermoid are described in the skin ,brain, .spleen and gonads(Cortez and Kaplan,1993;Dieckmann and Loy ,1994). The authors suggested that these cysts may be misdiagnosed as dermoids or teratoma which they have different histological features(Nielsen and Kennedy,1990).

In the human literature, dermoids are also called benign cystic teratoma and suggested as stratified squamous epidermis with adnexal structures, they usually contain a variety of tissues, including neural tissue, thyroid gland and mesenchymal proliferations.

All three embryonic layers may be found in the dermoids of human, Simple epidermoid cysts do not contain structures from the other embryonic germ layers (Price, 1969).Although human teratoma are of ten malignant ,teratomas rarely metastasize in domestic animals .In veterinary classification, dermoids only contain cutaneous tissue derivatives, where as teratoma contains tissues of two or three embryonic layers (Pantoia et al.,1975 and McEntee,1990).

In domestic animal species, teratoma is reported sporadically in male and female gonads, but they are most frequently into equine testis (Nielsen and Kennedy, 1990).

\section{Materials and Methods:}

The histological for 120 ovary samples were collected from different regions at south of Iraq, Study has been found three cases of abnormal ovaries (left and right) in cattle.. Macroscopically description has been reported for determined on three cases of ovary lesions by accurate inspection. Then routine histological sectioning has been performed in AlNassiria hospital (Luna, 1968) to determine the histopathological diagnosis. Further diagnosis was submitted to Pathologist from Faculty of Medicine. Digital photo and microscopically photo has been done in Faculty of Science.

\section{Results :}

\section{1-The anatomical study}

Left ovary had protruded recuitable cysts, in different size, which was seen as multiple; unrupture mature follicle .These cysts contained on offwhite, viscid-liquid material and visible hair that one of remnants structures 


\section{University of Thi-Qar Journal Vol.12 No.2 June 2017 \\ Web Site: https://jutq.utq.edu.iq/index.php/main \\ Email: journal@jutq.utq.edu.iq}

was embedded into liquid material. Also hair appeared from external surface of cysts obeviously.Longtudinal incision to ovary demonstrated that present large cyst which occupied the majority of internal surface as well as it contained on large amount of viscid -liquid material (Fig.1, 3).

In right ovary was showed that lesion was dark yellow, semisolid material and highly rich with blood vessels. Lesion similar to corpus luteum on ovary. The tumor lesion was mushroom like on lateral surface of ovary. Making of longitudinal incision to the ovary showed that fatty material into the touch was occupied majority of internal surface (Fig.2).

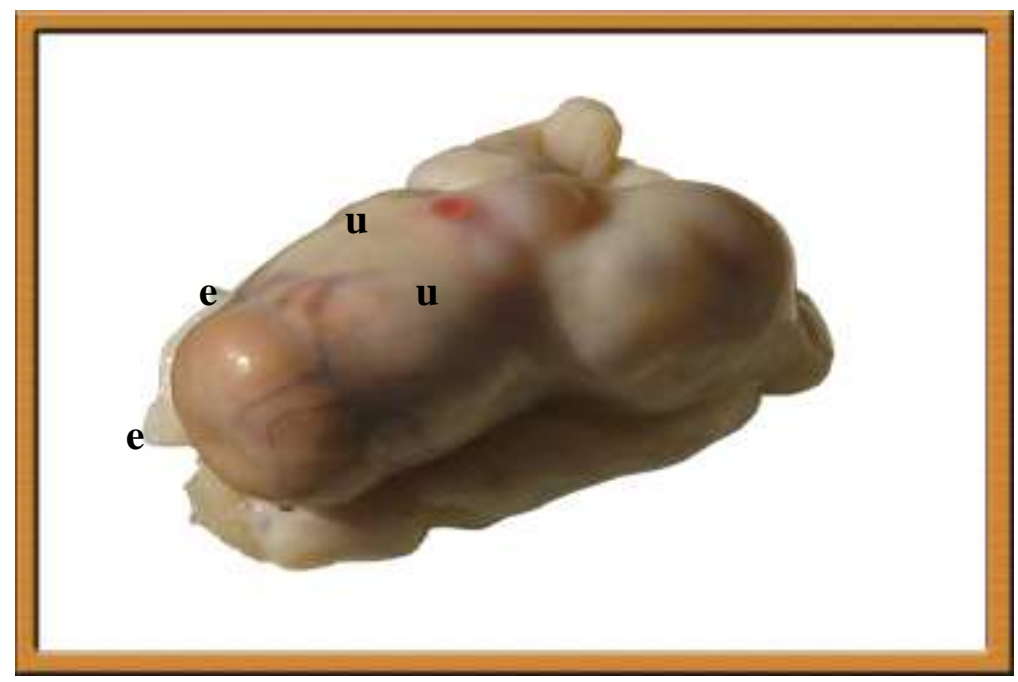

Fig.1 : ( a) Left ovary showed of (e) enlargement of corpus luteum and (u) unrupture follicles filled with high amount fluid

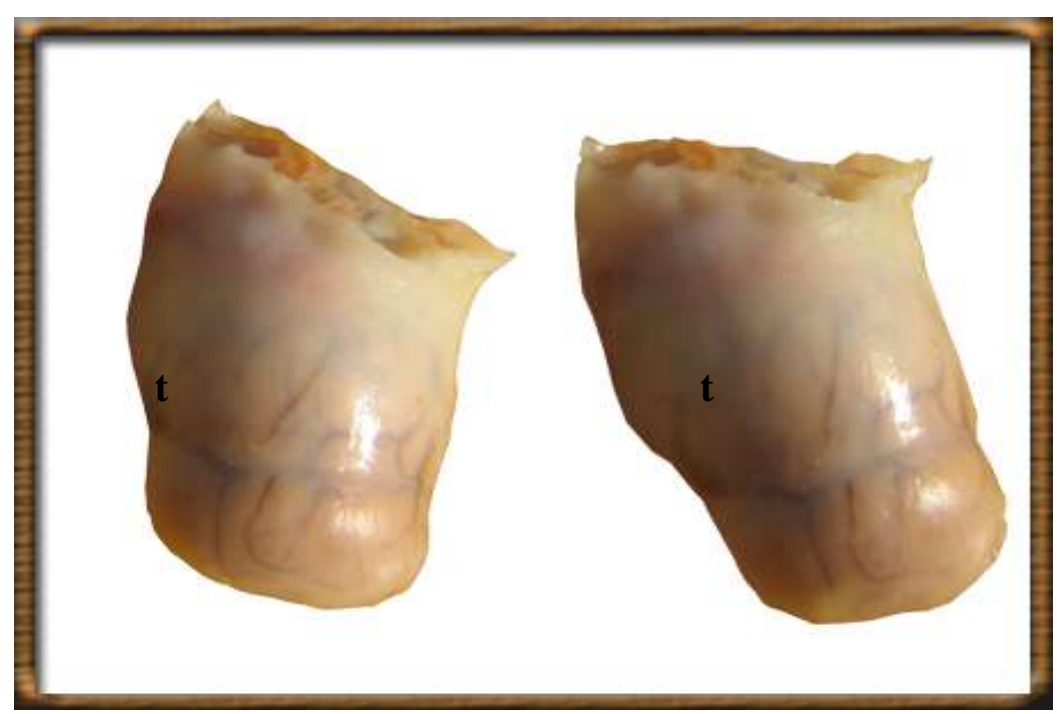


Web Site: https://jutq.utq.edu.iq/index.php/main

Email: journal@jutq.utq.edu.iq

Fig.2: Right ovary showed ( $t$ ) tumor of ovary with highly blood vessels invasion.

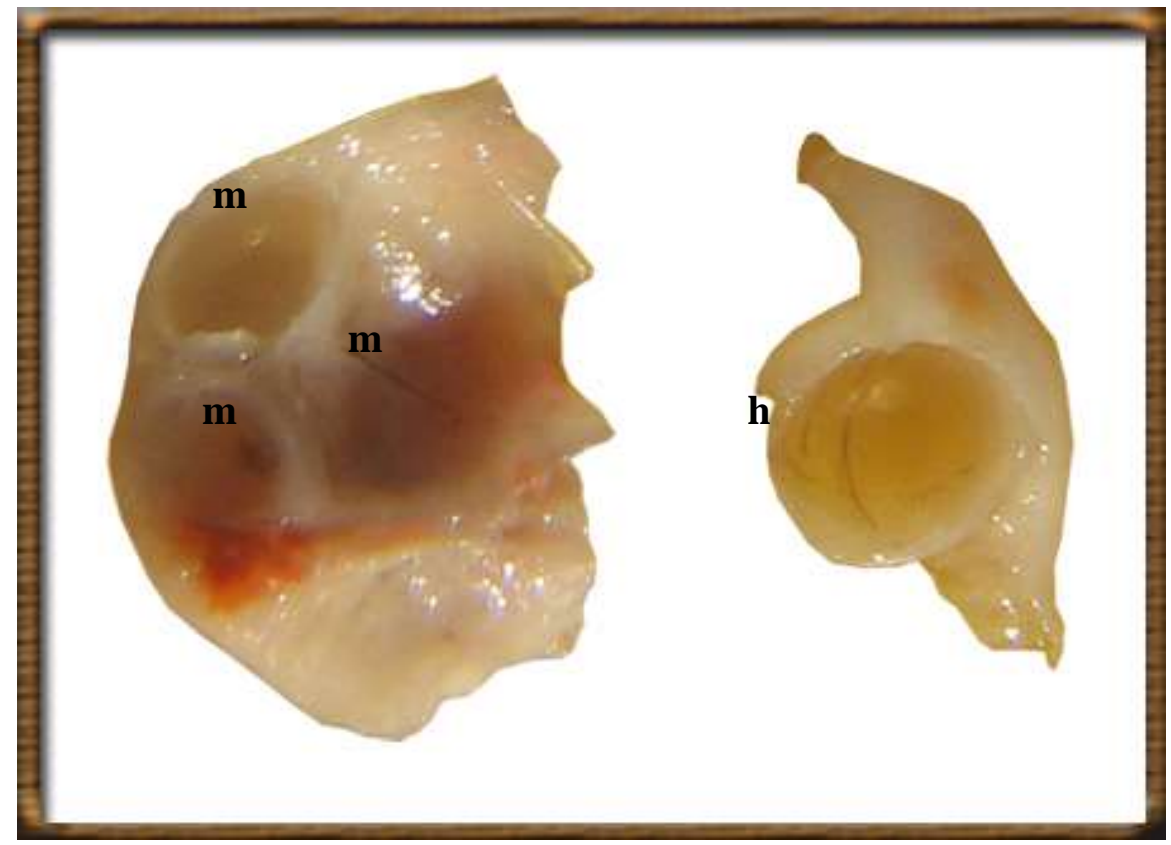

Fig.3: Grossly structure of ovary showed of ( $h$ )-visible hair within cyst ovary.(m) multicyst of ovary filled with viscid liquid material.

\section{2-The Histological study}

The histological results revealed that the ovary included were germinal layer contained of squamous epithelial cells which transformed to malignant cells in cortex. as well as cortex loss of structural constitutions, There is don't any stage of follicle development .Different stages of malignant cells were observed in stroma of cortex. These cells were surrounded cysts within cortex. Histological sections to confirm to occurrence under went mitotic division which appeared obviously. Demonstrated that the cortex contained large cyst was occupied most of it 


\section{University of Thi-Qar Journal Vol.12 No.2 June 2017 \\ Web Site: https://jutq.utq.edu.iq/index.php/main \\ Email: journal@jutq.utq.edu.iq}

and neoplasia granulosa cell were lined all cysts of cortex and extend into medulla. As well as it contained hair follicle.

These cells were characterized as keratinized stratified squamous epidermis cells and their neuclous had lateral in position due to the cells contained on large amount of keratin. Cystes contained on embryonic germ layer and Oocytes disappeared within it. Morefurther most keratin debris was lost during tissue processing in all cases (Fig.4, 5, 6, and 7). 
University of Thi-Qar Journal Vol.12 No.2 June 2017

Web Site: https://jutq.utq.edu.iq/index.php/main

Email: journal@jutq.utq.edu.iq

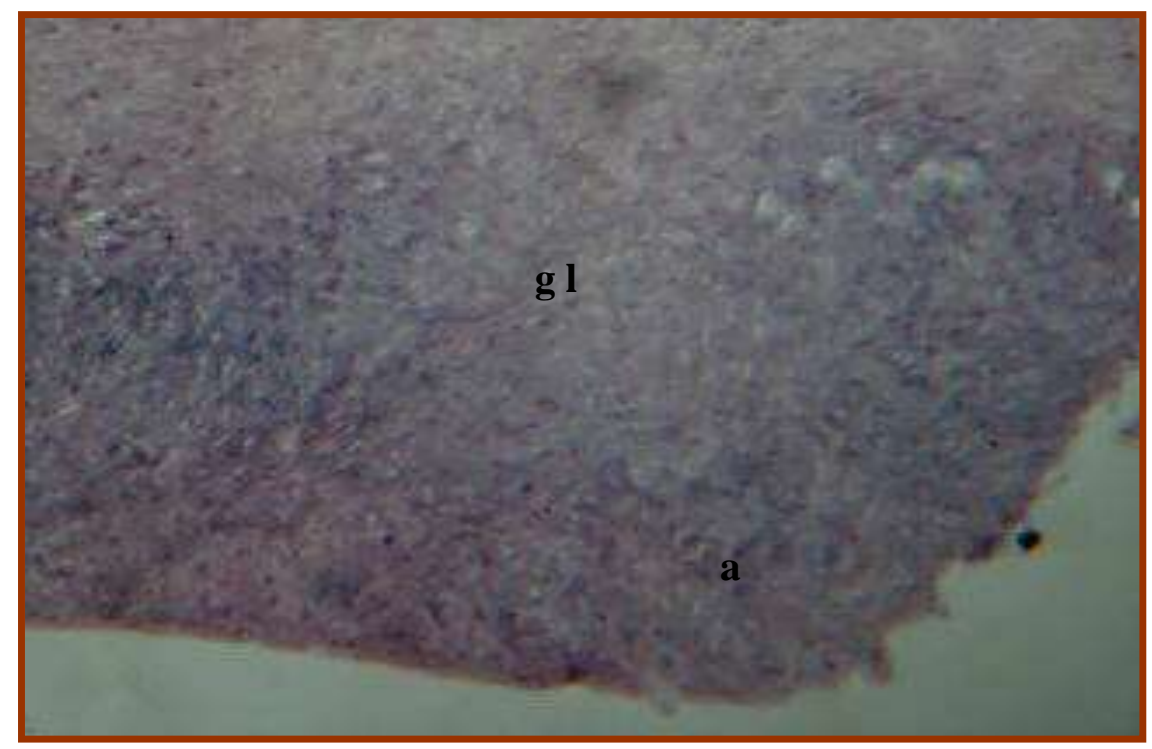

Figure (4): cross section of ovary lesion ( 40x).

(gl)surface of germinal layer ( a )absence of follicle development within cortex. $H \& S$ stain

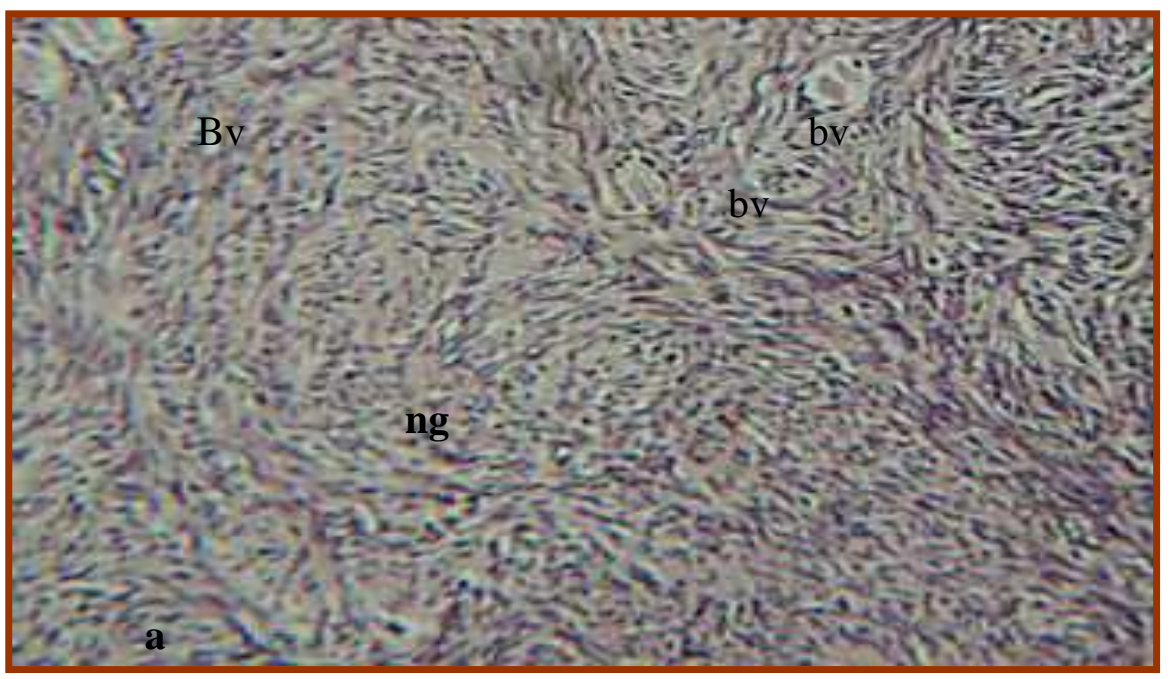

Fig(5):cross section of ovary lesion showed of (ng )neoplasia granulosa cells (bv)blood vessels .100x (H\&S stain). 
University of Thi-Qar Journal Vol.12 No.2 June 2017

Web Site: https://jutq.utq.edu.iq/index.php/main Email: journal@jutq.utq.edu.iq

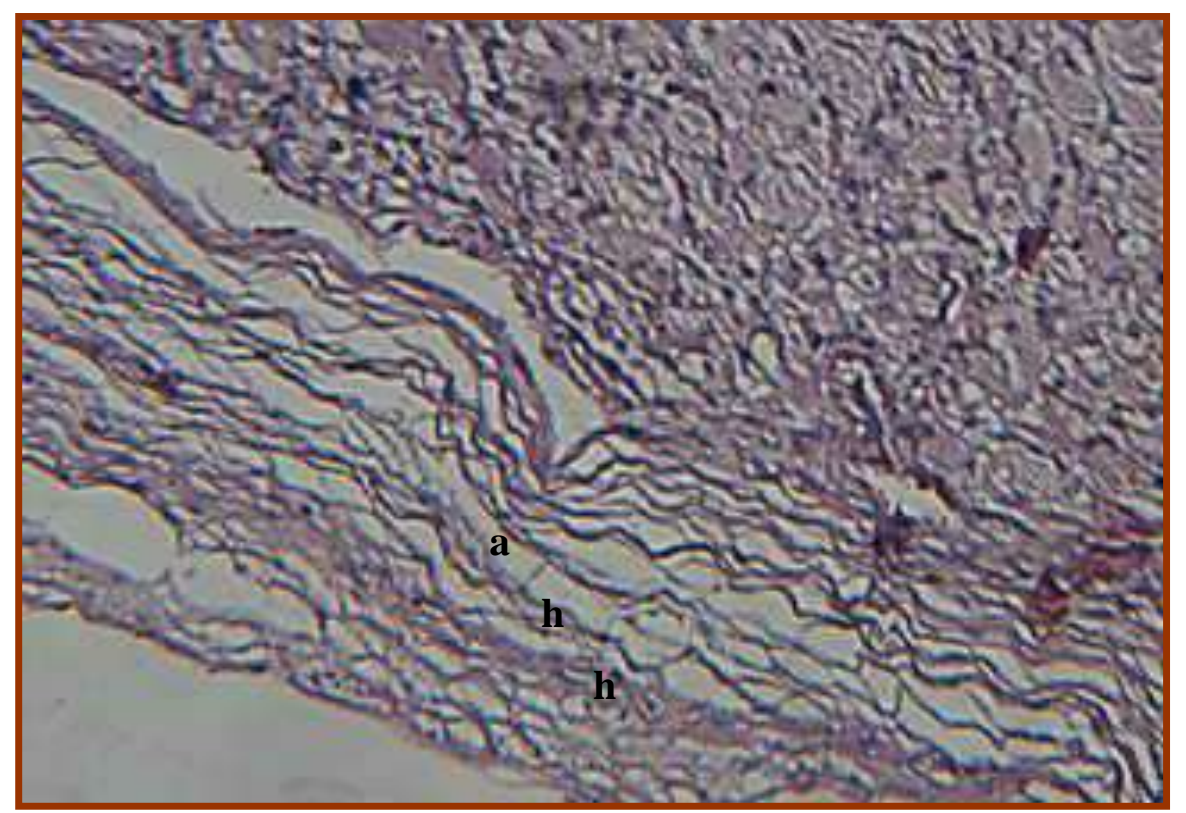

Figure (6): cross section of ovary lesion showed (h) hair follicle 4000x (H\&S stain).

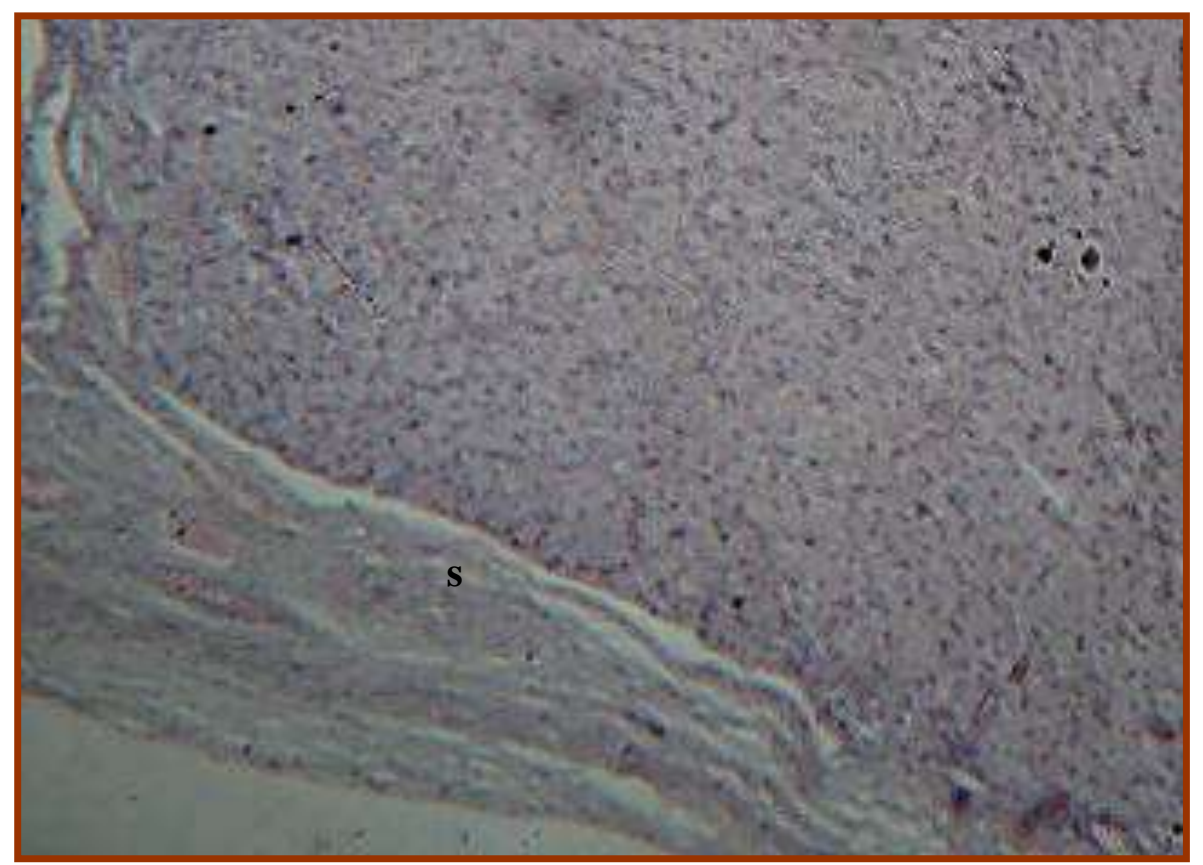

Fig.7:cross section of ovary lesion showed of( s)squamous cells 


\section{University of Thi-Qar Journal Vol.12 No.2 June 2017 \\ Web Site: https://jutq.utq.edu.iq/index.php/main \\ Email: journal@jutq.utq.edu.iq}

\section{0x (H\&S stain).}

\section{Discussion:}

In the present study, absolutely the closed similarity between teratoma and epidermal cysts of ovary was represented by the difficult differentiated and misdiagnosis between them, So that dependent on features of macroscopically and microscopically examinations for accurate diagnosis. The presence of lesions on bilateral of ovaries that indicated the tumor was malignant which compliance with human teratoma is often malignant (Dieckmann and Loy, 1994; Nielsen and Kennedy, 1990).

Description of macroscopically examination features are more compatible with description of some reported teratoma (Basile et al.,1998;McEntee,1990a,b).In domestic animal species,teratoma are reported sporadically in male and female gonads, but they are reported most frequently in the equine tests (Nielson \& Kennedy,1990) that slightly differences with the current study which to confirm until the teratoma was more frequently in cattle ovaries Also during the present study showed almost cattle were more incidence with teratoma compared with other studies had been referred to that cattle were rare at first time;Teratoma was reported at south of Iraq because of had been no reported any case with teratoma it the same region .

This study was agreement with study had been were more incidence to teratoma, generally. Histological study showed teratoma features which were malignant tumors, squamous metaplasia and interfering of cortex and medulla tissues which difficult separated between them. All that ,completely compared with (Edward and Vinay,2005 ).Important character in teratoma was represented the remnants of hair follicles structure in stroma of cortex that was full agreement with (Edward and Vinay,2005 ).Teratoma containing cysts lined by keratinizing that similar to study was reported by ( Pantoia et al.,1975).

\section{Conclusions:}

1-This study was the first reported of histopathological diagnosis of teratoma in south of Iraq.

2-High incidence of ovarian teratoma in cattle, in the study, where as the absent of previous reports of this condition in the veterinary literature. 


\section{University of Thi-Qar Journal Vol.12 No.2 June 2017 \\ Web Site: https://jutq.utq.edu.iq/index.php/main \\ Email: journal@jutq.utq.edu.iq}

3-The similarity of high incidence to teratoma between woman and cattle as compared with other large animals.

\section{References :}

1-Basile JR ;Diniz JMF and Basile LF.(1998 ). Teratoma multilocular no ovario de novilhas nelore no estado do Para.Semina and CiAgr Londrina ,19:79-82.

2-Cortez JC and Kaplan GW.(1993).Gondal stromal tumors ,gonadoblastomas, epidermoid cyses, and secondary tumors of the testis in Children. Urol. Clin. North Am., 20:15-25.

3-Dieckmann KP and Loy V.(1994) :Epidermoid cyst of testis :a review of Clinical and histogenetc considerations .Brit J. Urol .,73 : 436-441.

4-Edward, C. ;Vinay, K .Robbins and Cortan,I.( 2005). Review Of Pathology .2 end.U.S.A.Staunders Company.pp.871.

5-Luna,L.G.(1968): Manual of histologic staining methods of armed Forces institute of pathology $3^{\text {rd }}$.New York.U.S.A.PP:123.

6-McEntee K.(1990 ).Ovarian neoplasm. In Reproductive Pathology of Domestic Mammals, Academic Press, New York NY. pp.69-93

7-McEntee K.(1990). Scrotum, spermatic cord, and testis: prolifera lesions .In :Reproductive Pathology of Domestic Mammals .Academic Press, New York, NY. Pp.279-306.

8-Nielson SW and Kennedy PC.(1990).Tumors of the genital system .In : Tumors in Domestic Animals, ed.Moullton JE ,University of California Press, Los Angeles, CA. $3^{\text {rd }}$ ed., Pp.479-517.

9-Nogales FF and Silverberg SG.(1976). Epidermoid cysts of the ovary: a report of five cases with histogenetic considerations and Ultra structural findings. Am. J. Obst. Gyncol., 124:523-528

10-Pantoia E ; Noy MA;Axtmayer RW;Colon, FE and Pelegrina,I. (1975).Ovarian dermoids and their complications. Comprehensive Historical review. Obstes Gynecol Surv 30:1-20.

11-Price EB Jr: Epidermoid cysts of the testis: a clinical and Pathologic analysis of 69 cases from the testicular tumor .J.Urol., 102:708-713, 1969. 


\section{University of Thi-Qar Journal Vol.12 No.2 June 2017 \\ Web Site: https://jutq.utq.edu.iq/index.php/main \\ Email: journal@jutq.utq.edu.iq}

\section{دراسة نسيجية مرضية لتثخيص الورم النسخي في الابقار في جنوب العراق}

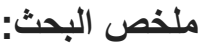

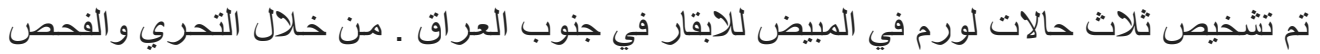

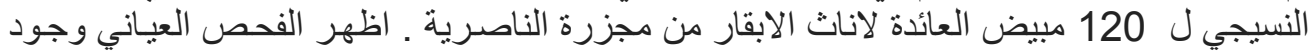

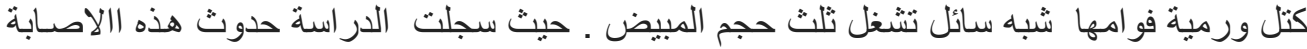

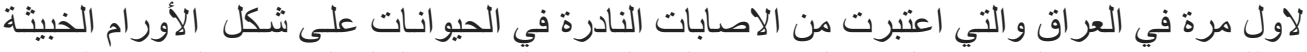

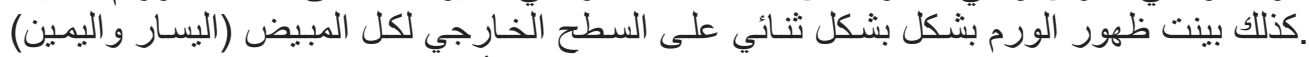

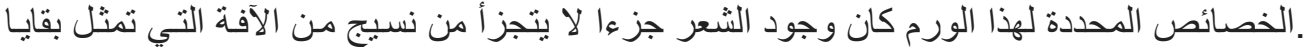

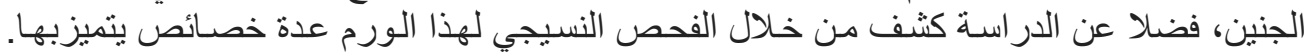

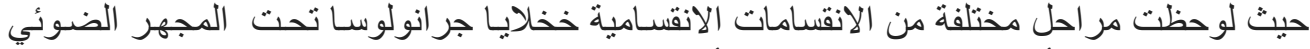

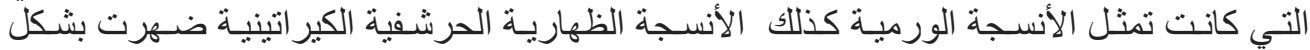

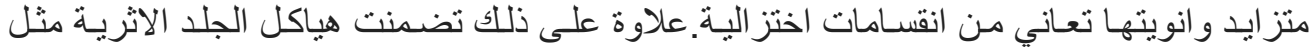

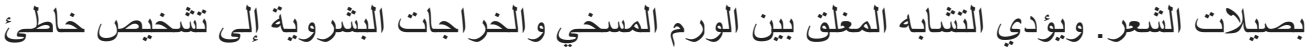

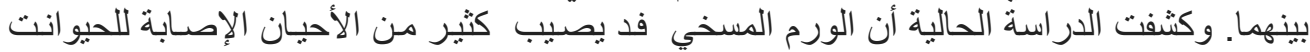

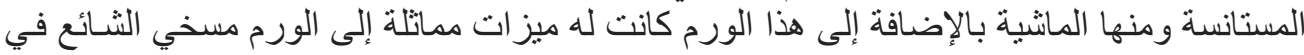

